\title{
DONORS AND NON-PROFIT ORGANISATIONS' ACCOUNTING MANIPULATIONS: AN OVERVIEW OF THE LITERATURE
}

\author{
Marc Jegers \\ Vrije Universiteit Brussel
}

\begin{abstract}
$\mathrm{T}$

There is almost no literature directly linking non-profit organisations' earnings manipulations to expected donor behaviour. Therefore, the literature on non-profit organisations' accounting manipulations is reviewed from the perspective of their expected effects on donations. It becomes clear that manipulations frequently aim at disclosing figures which are documented to be beneficial to the amount of funds raised. This provides enough ground to suggest strict accounting regulations for non-profit organisations, combined with audit engagements extended to the cost accounting information disclosed, despite some evidence that a majority of potential donors might not be interested at all in financial information.
\end{abstract}

\section{INTRODUCTION}

Non-profit organisations can be defined as organisations whose founders and employees are not entitled to (a part of) the organisation's profits (the 'non-distribution constraint' coined by Hansmann $(1987$, p. 28)). They are confronted with a multitude of stakeholders to which they are accountable, one important group of these being their donors. It goes without saying that overall accountability should relate to the organisation reaching its objectives, and that narrative and non-financial quantitative disclosures are essential for documenting this. Therefore, non-financial performance reporting should have a prominent role in the overall reporting practices of non-profit organisations (Falk, 1992; Hyndman, 1990; Parsons, 2003; Torres and Pina, 2003). However, strictly financial reporting, the focus of the present paper, cannot be discarded as being irrelevant, not only in terms of accountability, but also because of the empirically observed effects on the amount of funds raised. These funds are necessary to enable the organisation to pursue its objectives. Disclosed 
Jegers

financial statements, therefore, are one of the ways to mitigate information asymmetries between organisations and their donors, and can be used by the latter to assess the organisations' financial health and needs. If this assessment affects donor behaviour, non-profit organisations have an incentive to present the relevant financial data as favourably as possible, to raise as much funds as possible. One might therefore expect to find numerous research papers on the relationship between accounting manipulations and donations, but nothing is further from the truth.

As far as can be ascertained, there is only one theoretical paper developed on this relationship (Jegers, forthcoming). It proposes a comprehensive formal model of earnings manipulations, taking the impact of disclosed earnings on externally raised funds into consideration. Both risk-neutral and risk-averse managers are assumed to function in a principal-agent setting in which the organisations' boards are the principals. This model remains fundamentally unchanged when donors are considered principals, as long as it is accepted that their objective is activity maximisation. Managerial objectives are assumed to be budget related (Steinberg, 1986). Power distribution between the board and management determines the eventual weights of activity level and budget in the organisational objective function, which is maximised. The impact of reported earnings $\Pi_{\mathrm{M}}$ on donations $F$ is assessed by assuming $\partial \mathrm{F} / \partial \Pi_{\mathrm{M}}$ to be monotonically positive (one of the many forms of 'crowding-in'), zero or monotonically negative ('crowding-out'). It is proved that, without crowding-out or crowding-in, it is not optimal for the organisation to manipulate earnings. Otherwise, under both crowding-out and crowding-in, more managerial power leads to more earnings manipulation, and therefore to a larger impact on donations.

As far as the empirical work is concerned, there is literature available on the impact of disclosed financial data on donor behaviour and non-profit organisations' accounting manipulations. Both strands of the literature will be reviewed in the next section. The extensive literature on donor motives, as described, for example, by Andreoni (1990) or Rose-Ackerman (1996), will not be taken into consideration, as this is only indirectly relevant to the present paper's main topic. The paper closes with some conclusions and policy recommendations.

\section{ACCOUNTING INFORMATION AND DONATIONS}

Most of the empirical literature focuses on the relationship of donations with the 'price' of donations: the outlay of the donor net of personal tax advantages $(F(1-t)$, $F$ being the gross outlay and $t$ the tax rate to be applied), divided by the costs borne by the organisation to pursue its objectives ('programme' costs). The latter can be obtained from published financial statements, as long as they provide the allocation of all costs $(C)$ to cost objects, some of which reflect these objectives. Ignoring for the moment tax deductible costs, a simple system of cost objects consists of having administration costs $(A)$, fundraising costs $(f)$ and programme costs $(C-A-f)$. The price of programme activities then can be estimated by calculating

$F(1-t) /(C-A-f)$ 
The literature reviews by Parsons (2003) and Jacobs and Marudas (2009) show that donations, admittedly from all kinds of sources, in general are negatively correlated with this price variable. The strength of the correlation differs between industries (Brookes, 2007) and also depends on the donors' sizes (Tinkelman, 1998). Tinkelman and Mankaney (2007) also establish that there is a relationship between donations and donation prices only when the price data are reliable and relevant. These relationships might partly be induced by the availability and frequent use of watchdog standards (Bhattacharya and Tinkelman, 2009).

However, there are a number of conceptual problems with the donation price variable, apart from the accounting manipulation possibilities discussed in the next section. The first is the observation that only programme costs are taken into consideration, and not output itself, thus ignoring possible efficiency differences between organisations (Parsons, 2003). The second is that, from a theoretical point of view, average values are bad guides when it comes to identifying the organisations to which additional donations would result in a maximal output increase. Admittedly, in practice marginal activities are difficult, if not impossible, to determine. The last point is that subtracting total administrative costs and fundraising costs is not really appropriate, as a certain amount of administration is necessary to make programme activities possible, as are some fundraising efforts to raise funds. Therefore, the mere presence of these costs is not an indication of inefficiency: there can be too much, or too little, of them. Kähler and Sargeant (2002) provide a benchmarking exercise for administration costs, taking into consideration a size effect. This is appropriate as a (large) part of the administration costs can be expected to be fixed. For anecdotal reference, the highest value of $A / C$ observed in their sample of 410 English and Welsh charities was an astonishingly high 0.43 (Kähler and Sargeant, 2002).

On top of these conceptual issues, one cannot be sure that the potential donors bother at all about costs or donation prices (Hyndman, 1990). This has also been observed in a laboratory experiment by Buchheit and Parsons (2006): only 37 per cent of their test subjects (157 undergraduate management accounting students) were interested in making a financial comparison between organisations competing for donations. The good news is that 89 per cent of them eventually donated to the most efficient organisation, as measured by $(C-A-f) / C$.

Other ways through which financial information might influence donations are crowding-in and crowding-out mechanisms with respect to subsidies: the knowledge of organisations receiving ample subsidies might either be considered by potential donors as a reliable signal indicating the organisation is trustworthy, making them donate to that organisation (crowding-in), or as a reason to consider their gifts less necessary, so they refrain from donating (crowding-out). The two effects are not mutually exclusive, and their combined result is not a priori constant across industries (Smith, 2007) or across different subsidy levels (Borgonovi, 2006). It goes without saying that both mechanisms can only describe reality if potential donors indeed read and correctly understand the subsidy data contained in nonprofit organisations' financial statements. Institutional donors can be expected to have the necessary expertise for this, but this is not necessarily the case for individual donors: Horne, Johnson and Van Slyke (2005) establish that, in a sample of 675 donors in the state of Georgia (United States (US)), 45 per cent did not have any 
Jegers

clue about the subsidies received by the organisation they donated to, whereas only 28 per cent of the sample managed to make a correct estimate within (broad) 10 per cent limits. Clearly, in such a situation the impact of accounting information on donor behaviour, if any, can only be labelled as modest.

Crowding-in or crowding-out can also be at work in the relationship between a donation and the (reported) wealth of the organisation (Chase and Coffman, 1994): higher levels of wealth are considered to be either a reason to reduce donations ('political cost'), or a signal of financial viability, entailing more gifts, which are then expected not to be wasted. Apparently, here the public is assumed not to be able to correctly assess the disclosed data.

In countries where tax regulations require non-profit organisations to make a distinction between taxable activities and non-taxable activities, another way to affect donations is the allocation of indirect costs to taxable cost centres and non-taxable cost centres. For the non-taxable cost centres, the aforementioned administration costs, fundraising costs and programme costs are direct costs. Here, organisations could be inclined to allocate as much as possible of their indirect costs to the nontaxable activities, in order to show as high as possible programme costs. This implies balancing higher gifts and lower taxes payable. Note, however, that shifting costs away from non-taxable activities to taxable activities reduces the reported cost of the former, which then appear to have performed more efficiently if output measures are available, possibly inciting potential donors to start or increase donations.

A last way by which accounting information can influence donations is through the assessment of the organisation's performance by rating agencies, which is predominantly achieved by using disclosed financial data. In a recent paper by Gordon, Knock and Neely (2009), a positive correlation was reported between rating changes and both donation levels and changes in a sample of 405 organisations receiving at least $\$ 500,000$ USD yearly in public support, followed by the US-based Charity Navigator (website data retrieved in 2007 (Gordon et al., 2009)). Silvergleid (2003) provides an overview of US watchdog agencies and finds mixed results as to their impact on donations.

\section{ACCOUNTINGS MANIPULATIONS POSSIBLY AFFECTING DONATIONS}

\section{Definition}

If donors are influenced by disclosed accounting data, non-profit organisations experience an incentive to present their financial data in a way that elicits as many donations as possible. This can be done within the confines of accounting regulations, or beyond them. Both types of actions will be called in the present paper 'manipulations', as the focus is on presenting financial data differently from how they would be, if their effect on donations and the legality of the actions were not taken into consideration.

\section{Donation-Related Manipulations}

When considering potential donors, non-profit organisations have an incentive to guide indirect cost allocations in a way that signals high activity levels (Trussel, 
2003), especially when programme costs are disclosed together with administrative costs and fundraising costs. Krishnan, Yetman and Yetman (2004) present empirical evidence of this: comparing the data of 719 hospital-year observations (Californian non-profit hospitals, 1994-1998) in two databases that should contain the same data, they found that, on average, programme expenses reported in the publicly available database exceeded the same expenses reported in the other database, which was non-accessible by the general public, by $\$ 13.9$ million USD (Krishnan et al., 2004). Furthermore, of the 95 hospitals reporting no fundraising expenses at all, at least 19 appear to have publicly observable fundraising activities (Krishnan et al., 2004), apparently shifting the fundraising costs maximally to programme costs and/or administration costs, and not to the fundraising cost centre. A comparable result is found by Tinkelman (2006): in two samples of, respectively, more than 17,000 New York-based contribution-receiving organisations and more than 16,000 US contribution-receiving organisations (1992-1994), about 50 per cent reported fundraising expenses lower than 1 per cent of contributions. In their later paper, Krishnan, Yetman and Yetman (2006) also found that the probability of not reporting any fundraising costs increases with the intensity of the relationship between donations and the share of the total costs that are programme costs. The same conclusion is reached when looking at the relationship between managerial remuneration and the share of programme costs. Finally, Keating, Parsons and Roberts (2008) establish in their sample of 4,063 observations, on 1,382 US non-profit organisations (19992004) located in eight states, that misreporting the cost of telemarketing campaigns might lead to an underestimation of the fundraising share of total costs by up to 15 per cent. The larger, more professional and more intensely monitored organisations are found to publish less misreporting, leading the authors to the suggestion that at least part of the misreporting might be explained by lack of accounting knowledge. Deliberate manipulation is therefore not the only possible explanatory factor.

Jones and Roberts (2006) do not look at programme activity share increasing manipulations, but at manipulations to dampen programme activity share variability. In their sample of 708 organisation-year observations of US non-profit organisations (1992-2000), they indeed see such behaviour. Potential donors might consider less variable activity shares as an indication of lower risk, making them more reassured when donating.

As to wealth reporting, the choice between fair market value reporting of the endowment and reporting the endowment at cost is considered in a sample of 137 private colleges and universities in the US (data pertaining to 1989) (Chase and Coffman, 1994). The results show that the institutions choosing the fair market value method are more endowed, supporting the financial viability reasoning.

The papers by Cordes and Weisbrod (1998; on 1,476 US non-profit organisations from the arts, education, health and human services industries, with data from 1992) and Yetman (2001; on 703 US non-profit organisations from the education, health and charity industries, with data from 1995-1997) document cost-shifting behaviour towards taxable activities. An opposite pattern is not apparent when looking at the allocated (aggregated) revenues (Yetman, Yetman and Badertscher, 2009; on 1,612 US organisation-years for 1995-1997). This is also reported by Omer and Yetman (2003), who show taxable incomes to cluster in a non-random way 
Jegers

around zero. A number of organisations seem to be too zealous when shifting costs: in the US, more than half of the organisations reporting 'unrelated business income' report not making profits on it. Furthermore, the aggregate value of losses exceeds that of profits (Sinitsyn and Weisbrod, 2008, referring to work by Riley with Internal Revenue Service data up to 2002). One can only hope that applying creative allocation rules is the explanation for this situation, and not engaging in unprofitable 'profit' activities. This is exactly inferred by Sinitsyn and Weisbrod (2008), who show, in a sample of 11,036 observations (1993-1997) of US non-profit organisations in six broad industries, increased allocation of depreciation costs of assets used jointly for taxable and non-taxable activities to the taxable result when there is a possibility to reduce taxes by doing so. They also observe that the choice of taxable activities is not random, but possibly guided by the presence of assets that can be jointly used.

Finally, to the best of this author's knowledge, no empirical work is available on manipulations of disclosed subsidy levels. Furthermore, the relationship between manipulations and donations is almost never directly assessed (see next section), though researching manipulations is frequently justified exactly by its potential effects on donations, through the well-documented relationships between some financial data and gifts described earlier.

\section{EARNINGS MANAGEMENT AND DONATIONS: DIRECT TESTS}

Contrary to the huge amount of accounting manipulations literature for for-profit organisations relating manipulations to the organisation's main objective (profits), there is little of it in the non-profit sphere, and almost nothing on the relationship with donations. This should not be a surprise, as the non-profit character of these organisations implies profits are not the most relevant peformance parameter. Therefore, the for-profit earnings manipulation research is not fully transferable to study non-profit manipulations, even though too high profits or too severe losses might influence donor generosity.

In a way, the aforementioned work by Chase and Coffman (1994) can be interpreted as a direct test of the link between manipulations and donations, when we consider endowment levels to be cumulated donations, including their yields.

There is also some empirical work on manipulations aiming at improving ratings, assuming these might boost donations. This policy is illustrated in the case of the Avon Breast Cancer Walks described by Tinkelman (2009). Bhattacharya and Tinkelman (2009), on the other hand, applying visual inspection and statistical testing of ratio distributions, do not observe manipulations to reach watchdog-issued standards on a programme activity ratio and a fundraising cost ratio (111,894 US organisations for 2001). However, they acknowledge that this does not imply that there is no manipulation, as their sample consists only of organisations reporting non-zero administrative and fundraising costs (only 24 per cent of the total population (Bhattacharya and Tinkelman, 2009)). 


\section{CONCLUSIONS}

Though there has been ample research on the link between non-profit organisations' financial disclosures and the level of gifts raised, and a substantial amount on non-profit organisations' accounting manipulations, the link between manipulations and donations has hardly been explicitly looked at, either from a theoretical perspective or empirically. Furthermore, the available research on non-profit organisations' earnings management/manipulations, a very popular topic when studying for-profit organisations, is (understandably) scant. There is no empirical work available on manipulations of disclosed subsidy levels, despite their role in crowding-in or crowding-out gifts. On the contrary, much attention has been given to nonprofit organisations' cost accounting manipulations, a topic almost never touched upon for for-profit organisations. The reasons for this might be twofold: donors are assumed to be affected by cost accounting data, such as the price of donations, and organisations therefore (have to) disclose them.

When looking at the literature on non-profit organisations' accounting manipulations, we observe that manipulations frequently aim at disclosing financial data in ways known to stimulate potential donors to make or increase gifts, despite some evidence that a majority of potential donors might not be interested at all in financial information. Therefore, from a policy point of view, accounting regulations (for both financial accounting and cost accounting) should be as strict as reasonably possible, narrowing down as much as possible the scope for non-profit organisations to present themselves in a way that would alter potential donors' behaviour. Finally, as also suggested by Tate (2007), extending auditing to cost accounting disclosures might prove useful. From a social welfare point of view, these measures will reduce the problem of misallocating gifts from donors relying on financial information.

\section{ACKNOWLEDGMENTS}

The thoughtful comments of two anonymous referees allowed me to substantially improve this paper's quality. As usual, they cannot be held responsible for any remaining errors.

\section{REFERENCES}

Andreoni, J. (1990). Impure Altruism and Donations to Public Goods: A Theory of Warm Glow Giving, The Economic Journal, Vol. 100, No. 401, pp. 464-477.

Bhattacharya, R. and Tinkelman, D. (2009). How Tough are Better Business Bureau/Wise Giving Alliance Financial Standards?, Nonprofit and Voluntary Sector Quarterly, Vol. 38, No. 3, pp. 467-489.

Borgonovi, F. (2006). Do Public Grants to American Theatres Crowd-Out Private Donations?, Public Choice, Vol. 126, Nos. 3-4, pp. 429-451. 
Jegers

Brooks, A.C. (2007). Income Tax Policy and Charitable Giving, Journal of Policy Analysis and Management, Vol. 26, No. 3, pp. 599-612.

Buchheit, S. and Parsons, L.M. (2006). An Experimental Investigation of Accounting Information's Influence on the Individual Giving Process, Journal of Accounting and Public Policy, Vol. 25, No. 6, pp. 666-686.

Chase, B.W. and Coffman, E.N. (1994). Choice of Accounting Method by Not-For-Profit Institutions: Accounting for Investments by Colleges and Universities, Journal of Accounting and Economics, Vol. 18, No. 2, pp. 233-243.

Cordes J.J. and Weisbrod, B.A. (1998). Differential Taxation of Nonprofits and the Commercialization of Nonprofit Revenues, Journal of Policy Analysis and Management, Vol. 17, No. 2, pp. 195-214.

Falk, H. (1992). Towards a Framework for Not-For-Profit Accounting, Contemporary Accounting Research, Vol. 8, No. 2, pp. 468-499.

Gordon, T.P., Knock, C.L. and Neely, D.G. (2009). The Role of Rating Agencies in the Market for Charitable Contributions: An Empirical Test, Journal of Accounting and Public Policy, Vol. 28, No. 6, pp. 469-484.

Hansmann, H.B. (1987). Economic Theories of Nonprofit Organizations, in W.W. Powell (ed.), The Nonprofit Sector: A Research Handbook, New Haven, CT: Yale University Press.

Horne, C.S., Johnson, J.L. and Van Slyke, D.M. (2005). Do Charitable Donors Know Enough - and Care Enough - about Government Subsidies to Affect Private Giving to Nonprofit Organizations?, Nonprofit and Voluntary Sector Quarterly, Vol. 34, No. 1, pp. 139-149.

Hyndman, N. (1990). Charity Accounting - An Empirical Study of the Information Needs of Contributors to UK Fund Raising Charities, Financial Accountability and Management, Vol. 6, No. 4, pp. 295-307.

Jacobs, F.A. and Marudas, N.P. (2009). The Combined Effect of Donation Price and Administrative Inefficiency on Donations to US Nonprofit Organizations, Financial Accountability and Management, Vol. 25, No. 1, pp. 33-53.

Jegers, M. (forthcoming). The Effect of Board-Manager Agency Conflicts on Nonprofit Organizations' Earnings and Cost Allocation Manipulations, Accounting and Business Research.

Jones, C.L. and Roberts, A.A. (2006). Management of Financial Information in Charitable Organizations: The Case of Joint-Cost Allocations, Accounting Review, Vol. 81, No. 1, pp. 159-178.

Kähler, J. and Sargeant, A. (2002). The Size Effect in the Administration Cost of Charities, European Accounting Review, Vol. 11, No. 2, pp. 215-243.

Keating, E.K., Parsons, L.M. and Roberts, A.A. (2008). Misreporting Fundraising: How Do Nonprofit Organizations Account for Telemarketing Campaigns?, Accounting Review, Vol. 83, No. 2, pp. 417-446.

Krishnan, R., Yetman, M.H. and Yetman, R.J. (2004). Financial Disclosure Management by Nonprofit Organizations, working paper, University of California at Davis.

Krishnan, R., Yetman, M.H. and Yetman, R.J. (2006). Expense Misreporting in Nonprofit Organizations, Accounting Review, Vol. 81, No. 2, pp. 399-420.

Omer, T.C. and Yetman, R.J. (2003). Near Zero Taxable Income Reporting by Nonprofit Organizations, Journal of the American Taxation Association, Vol. 25, No. 2, pp. 19-34.

Parsons, L.M. (2003). Is Accounting Information from Nonprofit Organizations Useful to Donors? A Review of Charitable Giving and Value-Relevance, Journal of Accounting Literature, Vol. 22, pp. 104-129.

Rose-Ackerman, S. (1996). Altruism, Nonprofits, and Economic Theory, Journal of Economic Literature, Vol. 34, No. 2, pp. 701-728.

Silvergleid, J.E. (2003). Effects of Watchdog Organizations on the Social Capital Market, New Directions for Philanthropic Fundraising, Vol. 41, Fall, pp. 7-26. 
Sinitsyn, M. and Weisbrod, B.A. (2008). Behavior of Nonprofit Organizations in For-Profit Markets: The Curious Case of Unprofitable Revenue-Raising Activities, Journal of Institutional and Theoretical Economics, Vol. 164, No. 4, pp. 727-750.

Smith, T.M. (2007). The Impact of Government Funding on Private Contributions to NonProfit Performing Arts Organizations, Annals of Public and Cooperative Economics, Vol. 78, No. 1, pp. 137-160.

Steinberg, R. (1986). The Revealed Objective Functions of Nonprofit Firms, RAND Journal of Economics, Vol. 17, No. 4, pp. 508-526.

Tate, S.L. (2007). Auditor Change and Auditor Choice in Nonprofit Organizations, Auditing: A Journal of Practice and Theory, Vol. 26, No. 1, pp. 47-70.

Tinkelman, D. (1998). Differences in Sensitivity of Financial Statement Users to Joint Allocations: The Case of Nonprofit Organizations, Journal of Accounting, Auditing and Finance, Vol. 13, No. 4, pp. 377-393.

Tinkelman, D. (2006). The Decision-Usefulness of Nonprofit Fundraising Ratios: Some Contrary Evidence, Journal of Accounting, Auditing and Finance, Vol. 21, No. 4, pp. 441-462.

Tinkelman, D. (2009). Unintended Consequences of Expense Ratio Guidelines: The Avon Breast Cancer Walks, Journal of Accounting and Public Policy, Vol. 28, No. 6, pp. 485-494.

Tinkelman, D. and Mankaney, K. (2007). When Is Administrative Efficiency Associated with Charitable Donations?, Nonprofit and Voluntary Sector Quarterly, Vol. 36, No. 1, pp. 41-64.

Torres, L. and Pina, V. (2003). Accounting for Accountability and Management in NPOs: A Comparative Study of Four Countries: Canada, the United Kingdom, the USA and Spain, Financial Accountability \& Management, Vol. 19, No. 3, pp. 265-285.

Trussel, J.M. (2003). Assessing Potential Accounting Manipulation: The Financial Characteristics of Charitable Organizations with Higher than Expected Program-Spending Ratios, Nonprofit and Voluntary Sector Quarterly, Vol. 32, No. 4, pp. 616-634.

Yetman, M.H., Yetman, T.J. and Badertscher, B. (2009). Calibrating the Reliability of Publicly Available Nonprofit Taxable Activity Disclosures: Comparing IRS900 and IRS900-T Data, Nonprofit and Voluntary Sector Quarterly, Vol. 38, No. 1, pp. 95-116.

Yetman, R.J. (2001). Tax-Motivated Expense Allocations by Nonprofit Organizations, Accounting Review, Vol. 76, No. 3, pp. 297-311. 